\title{
A water-soluble [60]fullerene-derivative stimulates chlorophyll accumulation and has no toxic effect on Chlamydomonas reinhardtii*
}

\author{
Jakub Lang1', Mariia Melnykova1, Michele Catania', Alicja Inglot' ${ }^{1}$ Aleksandra Zyss', \\ Katarzyna Mikruta1', Daria Firgolska', Agata Wieremiejczuk', Izabela Książek¹, Maciej Serda²®, \\ Paweł Nalepa², Bartosz Pluciński ${ }^{1}$, Aleksandra Giza ${ }^{3}$ and Paweł Jedynak ${ }^{1 \otimes}$
}

'Department of Plant Physiology and Biochemistry, Faculty of Biochemistry, Biophysics and Biotechnology, Jagiellonian University in Krakow, Kraków, Poland; 2 Institute of Chemistry, Faculty of Mathematics, Physics and Chemistry, University of Silesia in Katowice, Katowice, Poland; ${ }^{3}$ Department of Plant Biotechnology, Faculty of Biochemistry, Biophysics and Biotechnology, Jagiellonian University in Krakow, Kraków, Poland

\begin{abstract}
Chlamydomonas reinhardtii (WT 2137) P. A. Dang. (Volvocales, Chlorophyceae) is a green microalgae serving as a suitable model in scientific research and a promising industrial biotechnology platform for production of biofuel, hydrogen and recombinant proteins. Fullerenes $\left(C_{60}\right)$ are allotropic carbon nanoparticles discovered in 1985 and used in biomedical studies since the early 1990s, when water solubilization methodologies were developed. Recently, surface-modified hydroxylated derivatives of fullerenes were proven to enhance algal growth and drought tolerance in plants. Here, a novel type of water-soluble [60]fullerene derivative with 12 glycine residues (GF) has been synthesized and tested for acute toxicity (up to $50 \mu \mathrm{g} / \mathrm{ml}$ ) and as a potential biostimulant of algal growth. The effects of GF on pigment composition and growth rate of Chlamydomonas reinhardtii were systematically investigated. Our results suggest that GF was not toxic, and no negative change in the pigment content and no stress symptoms were observed. No changes in the photosynthetic parameters based on the fluorescence of chlorophyll $a$ in Photosystem II (NPQ, $F_{v} / F_{m}, F_{v} / F_{0}, P I$ and $\left.R C / A B S\right)$ were observed. The GF had no effect on cell size and growth rate. At a concentration of $20 \mu \mathrm{g} / \mathrm{ml}$, GF stimulated chlorophyll accumulation in 3-day-old cultures.
\end{abstract}

Key words: Chlamydomonas reinhardtii, algae, [60]fullerene-derivative, chlorophyll, toxicity

Received: 31 March, 2019; revised: 16 May, 2019; accepted: 01 June, 2019; available on-line: 07 July, 2019

\e-mail: p.a.jedynak@gmail.com, pawel.jedynak@uj.edu.pl (PJ); maciej.serda@us.edu.pl (MS)

*A preliminary report on this subject was presented at the 46th Winter School of the Faculty of Biochemistry, Biophysics and Biotechnology, Jagiellonian University in Krakow, Zakopane, Poland, February 11th-15th, 2019

Acknowledgements: The authors thank the Department of Plant Physiology and Biochemistry FBB\&B for the support. Maciej Serda thanks the National Science Center (Poland) for the support (UMO2016/23/D/NZ7/00912)

Abbreviations: GF, water-soluble [60]fullerene derivative with 12 glycine residues; $F_{v} / F_{m}$ maximal quantum efficiency of Photosystem II; $F_{v} / F_{0}$ oxygen-evolving complex efficiency; PI, performance index; RC/ABS, the force generated by the RC concentration per antenna chlorophyll

\section{INTRODUCTION}

Engineered carbon nanomaterials have become more and more prevalent in industry, medicine and in preci- sion agriculture. Nanoparticles (Rizvi et al., 2017), and the fullerenes among them, arouse potential interests for biotechnology. Pristine fullerenes are water-insoluble carbon spheres, typically containing about 60 atoms of carbon and fullerene $\mathrm{C}_{60}$ has been the best studied one so far. Fullerenes became quickly recognized as generally detrimental or toxic to microbes, cyanobacteria, algae, plants and animals (Lin et al., 2009; Landa et al., 2012; Chen et al., 2018; 2019). Thus, their usage as biostimulants is limited, but on the other hand they can act as potential cytotoxic agents (Lucafo et al., 2013; Franskevych et al., 2017), and as carriers for targeted drug-delivery in cancer therapies (Prylutska et al., 2015; Lapin et al., 2017). In addition, fullerene supplementation may enhance the uptake and accumulation of toxic substances in plants grown on polluted soil (De La Torre-Roche et al., 2012).

In nanomedical literature, it is well described that the surface of fullerenes can be chemically modified, mainly by using the Bingel-Hirsch and Prato reactions, altering fullerene physical and chemical properties (reviewed in detail in: Goodarzi et al., 2017). Such a change affects the fullerenes biological activities and modulates their application as photosensitizers in photodynamic therapies and as in vivo transfection agents (Maeda-Mamiya et al., 2010; Sharma et al., 2011). The effects of water-soluble derivatives of fullerenes containing multiple hydroxyl (fullerol or fullerenol), amine and carboxyl groups were extensively studied in plants and animals (Ma \& Liang et al., 2010). Fullerenol may penetrate through the cell membrane (Foley et al., 2002). Carbon nanomaterials smaller than $500 \mathrm{~nm}$ in length can easily get through the plant cell wall. Fullerenes may passively pass across cell membranes (due to their high affinity to the hydrophobic phase) (Bedrov et al., 2008), but diffusion of fullerenol is a few orders of magnitude lower (Qiao et al., 2007). However, fullerene derivatives can be absorbed by endocytosis in animal (Zhang et al., 2009) and possibly plant cells, as endocytosis of carbon nanotubes was evidenced in the plant cells (Liu et al., 2009). Both, the fullerenes and fullerenol were shown to accumulate in the cytoplasm of living tobacco (Kole et al., 2013; Husen \& Siddigi, 2014) and rice cells (Lin et al., 2009).

Fullerene and its derivatives can act both, as prooxidative (Sayes et al., 2004; Grebowski et al., 2013; Huang et al., 2014; Yin et al., 2015) and antioxidative agents (Prylutska et al., 2008; Injac et al., 2013; Sachkova et al., 2017; Roy et al., 2018; Tyurin et al., 2018). It was found that 
fullerenol had generally no effect or tended to stimulate growth of photosynthetic organisms. In Arabidopsis thaliana, the hypocotyl length was increased and no other effects were observed (Gao et al., 2011). Fullerol treatment of Momordica charantia resulted in biomass increase by $54 \%$, an increase in yield by $128 \%$ and a significantly enhanced accumulation of phytomedicines (Kole et al., 2013). Fullerenol binds water molecules, thus greatly improving resistance of the sugar beet (Beta vulgaris) to drought stress (Borišev et al., 2016). In addition, fullerenol application had decreased oxidative stress elicited by water-deficient conditions (Borišev et al., 2016). Little is known about its impact on algae. Fullerenol treatment had increased cell density of Pseudokirchneriella subcapitata algae cultures (Gao et al., 2011). However, the negative effects of surface-modified fullerenes were also evidenced. The $\mathrm{C}_{70}\left(\mathrm{C}(\mathrm{COOH})_{2}\right)_{4-8}$ derivative had caused auxin transport abnormalities and deformation of the root tip, as well as had decreased the shoot growth in Arabidopsis thatiana (Liu et al., 2010). Fullerenol had also severely damaged the root cells of Allium cepa (Chen et al., 2010). However, the use of nanoparticles, including carbon allotropes, raises a question about their safety in the food chain and their environmental safety (Rico et al., 2011; Wang et al., 2018). Presence of $C_{60}$ in the sewage had a negative effect on activated sludge and methanogenesis during anaerobic digestion (Zhao et al., 2018), but removal of fullerenols was efficient $(>90 \%)$ and had no significant effect on the microorganism's activity (Wang et al., 2011). Thus, the presence of fullerenol poses little risk of pollution in terms of wastewater production. Taking the above into consideration, it can be assumed that at low cost and low risk of serious environmental pollution, fullerenes may be potentially used as stimulants of growth of microorganisms cultured in bioreactors.

Chlamydomonas reinhardtii is a green microalgae serving as a model in scientific research and a promising industrial biotechnology platform for production of biofuel, hydrogen and recombinant proteins (Scranton et al., 2015; Rasala et al., 2015; Scoma et al., 2015). Here, a novel type of water-soluble [60] fullerene derivative containing 12 glycine residues (GF) (Fig. 1) has been synthesized and tested for acute toxicity, and as a potential regulator for improvement of algal growth. Particularly,

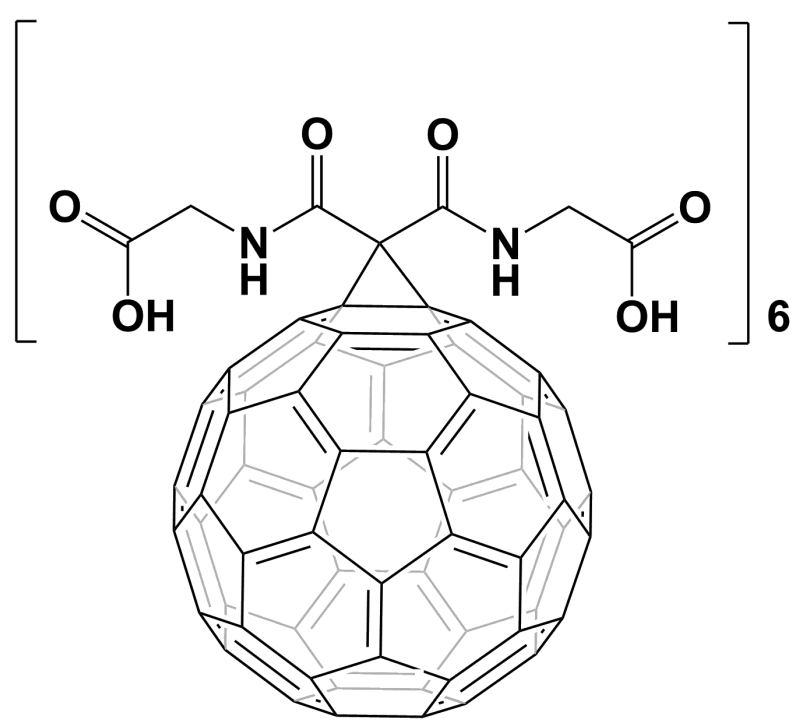

Figure 1. Chemical structure of GF, a [60]fullerene derivative containing 12 glycine residues the effect of GF on pigment composition and growth rate of $C$. reinhardtii were systematically investigated. Our results suggest that GF was not toxic and could moderately stimulate pigment accumulation in a $C$. reinhardtii culture.

\section{MATERIALS AND METHODS}

Materials for synthesis of fullerene derivatives. All compounds used were of reagent grade or better, solvents were used as received unless otherwise specified. The following reagents were used as received: $\mathrm{C}_{60}(99$. $5+\%$, MER Corp.), glycine (Acros Organics), DBU (1,8-diaza-bicyclo (5. 4. 0) undec-7-ene, Sigma Aldrich), malonic acid (Sigma Aldrich), $\mathrm{CBr}_{4}$ (Sigma Aldrich), and sodium hydride (Acros Organics). Nuclear magnetic resonance spectra were measured on a Bruker Avance III $500 \mathrm{MHz}$ NMR Spectrometer with tetramethylsilane as an internal standard. MS spectra for water-insoluble compounds were collected using an Autoflex II MALDI-TOF (Matrix Assisted Laser Desorption and Ionisation- Time Of Flight) mass spectrometer, and for water-soluble [60]fullerene derivatives by an MS electrospray ionization time-of-flight (ESI-microTOF) mass spectrometer, both instruments from Bruker DaltonicsInc. High resolution spectra were performed using Shimadzu IT (Ion Trap) and TOFLC-MS System, and flash chromatography was performed using Isolera Flash Purification System. The purity of all compounds was assessed using an Agilent1260 equipped with a DAD detector at $260 \mathrm{~nm}$, RP-column: Eclipse plus C18 (3.5 $\mu \mathrm{m})$; flow rate $0.5 \mathrm{ml} / \mathrm{min}$.

Highly water-soluble glycine derivative of [60]fullerene was synthesized using previously developed methodology (Serda et al., 2018a; Serda et al., 2018b).

Biological material and growth conditions. Axenic cultures of Chlamydomonas reinhardtii (WT 2137) P. A. Dang. (Volvocales, Chlorophyceae) were obtained from Dr. Itzhak Ohad, Hebrew University, Department of Biological Chemistry, Givet Ram, Jerusalem, Israel, in the 1990s and cultured in our laboratory (Prasad et al., 1998). Cultures were grown under continuous white light $(80$ $\mu \mathrm{mol} \times \mathrm{m}^{-2} \times \mathrm{s}^{-1}$ OSRAM L36W/77, Germany) with shaking (125 rpm) in a Sager-Granick medium (SagerGranick et al., 1953), supplemented with $100 \mathrm{mM}$ mannitol as an osmoprotectant, and sodium acetate $(75 \mathrm{mM})$, and citrate $(1.7 \mathrm{mM})$ as sources of organic carbon, with addition of soluble, surface-modified (containing amino acid residues) fullerenes to final concentration of $0 ; 20$; 40 and $50 \mu \mathrm{g} / \mathrm{ml}$. Samples were collected after 3, 6 and 9 days of cultivation.

Cell counting. The cells were counted using LUNAFl Dual fluorescence cell counter (Logos Biosystems, South Korea).

Fluorescence of chlorophyll $a$ in Photosystem II. Photosynthetic parameters were measured using HANDY PEA fluorimeter equipped with Liquid-Phase Chlorophyll Fluorescence Adapter for Handy PEA (Hansatech Instruments, United Kingdom). All fluorescence measurements were conducted after 15 minutes of adaptation of algal samples to darkness. Then, the maximal quantum efficiency of Photosystem II $\left(\mathrm{F}_{\mathrm{v}} / \mathrm{F}_{\mathrm{m}}\right)$, oxygen-evolving complex efficiency $\left(\mathrm{F}_{\mathrm{v}} / \mathrm{F}_{0}\right)$, the force generated by the chlorophyll in reaction center concentration per antenna chlorophyll (RC/ABS) and performance index $(\mathrm{PI})$ were simultaneously measured. Additionally, the non-photochemical quenching (NPQ) was measured us- 
ing Open FluorCam FC 800-O (Photon Systems Instruments, spol. s r. o., Czech Republic).

Pigment composition. Chlorophyll and carotenoid content were estimated spectrophotometrically (UV-Vis spectrophotometer, JASCO, United States), according to Lichtenthaler (1987).

Statistical analysis. For group comparison, we used the Kruskal-Wallis rank sum test (Hollander \& Douglas, 1973). Multiple comparisons between concentrations after Kruskal-Wallis test were done by the kruskalmc function from the pgirmess package (Siegel \& Castellan, 1988), using the R (version 3. 2. 4) system for statistical computing (R Core Team, 2019). P-values less than 0.05 were considered to be significant. Graphs were produced using Origin 7.0 (OriginLab). Each experiment was repeated in pentaplicate.

\section{RESULTS}

The GF had no statistically significant effect on accumulation of carotenoids and chlorophyll $b$ (Fig. 2B and D). The chlorophyll a content was significantly $(P<0.05)$ increased in 3-day-old cultures treated with $20 \mu \mathrm{g} / \mathrm{ml}$ of GF (Fig. 2A) and the same was observed for total $(a+b)$ chlorophyll concentration (Fig. 2C). Any other combination of GF concentration and time had no visible effect on the chlorophyll ( $a, b$ or total) content. No statistically significant effect on chlorophyll $a / b$ ratio (Fig. $2 \mathrm{E}$ ), nor chlorophyll to carotenoid ratio (Fig. 2F) was observed. The number of cells (Fig. 3A) in the control and GF-treated samples was similar, and the cell size decreased during the growth period in both, the control and tested cultures (Fig. 3B). Measurement of the chlorophyll a fluorescence in Photosystem II is a widely used technique of estimation of the physiological state of plants, for details see the following reviews (Maxwell \& Johnson, 2000; Misra et al., 2012; Kalaji et al., 2014). We have measured selected parameters related to chlorophyll $a$ fluorescence in Photosystem II. That allowed estimation of Photosystem II $\left(\mathrm{F}_{\mathrm{v}} / \mathrm{F}_{\mathrm{m}}\right)$ efficiency, the number of chlorophyll molecules per reaction center (RC/ABS) that in turn allows the estimation of the number of antennas in one reaction center, and $\mathrm{F}_{\mathrm{v}} / \mathrm{F}_{0}$ related to the efficiency of oxygen-evolving complex and the Performance Index (PI), which allow estimation of the overall photosynthesis efficiency. GF had no significant effect on any of these parameters (Fig. 3C-F). We have also measured fluorometrically the non-photochemical quenching (NPQ, the efficiency of thermal dissipation of energy form excited chlorophyll molecules during stressful, high-light conditions) of 9-day-old cultures and no differences between the GF-treated and the control samples were observed (Fig. 4).

\section{DISCUSSION}

Our results indicate that at a concentration up to 50 $\mu \mathrm{g} \mathrm{ml} \mathrm{m}^{-1}, \mathrm{GF}$ had no toxic effect on C. reinhardtii. GF had no negative effect on the pigment accumulation and did not interfere with photosynthesis and cell growth. No stress symptoms were observed. Pigment content and the chlorophyll to carotenoid ratio change dramatically under suboptimal conditions (e. g. salt stress) (Sairam \& Tyagi, 2004; Hussein et al., 2014) and may be accompa-
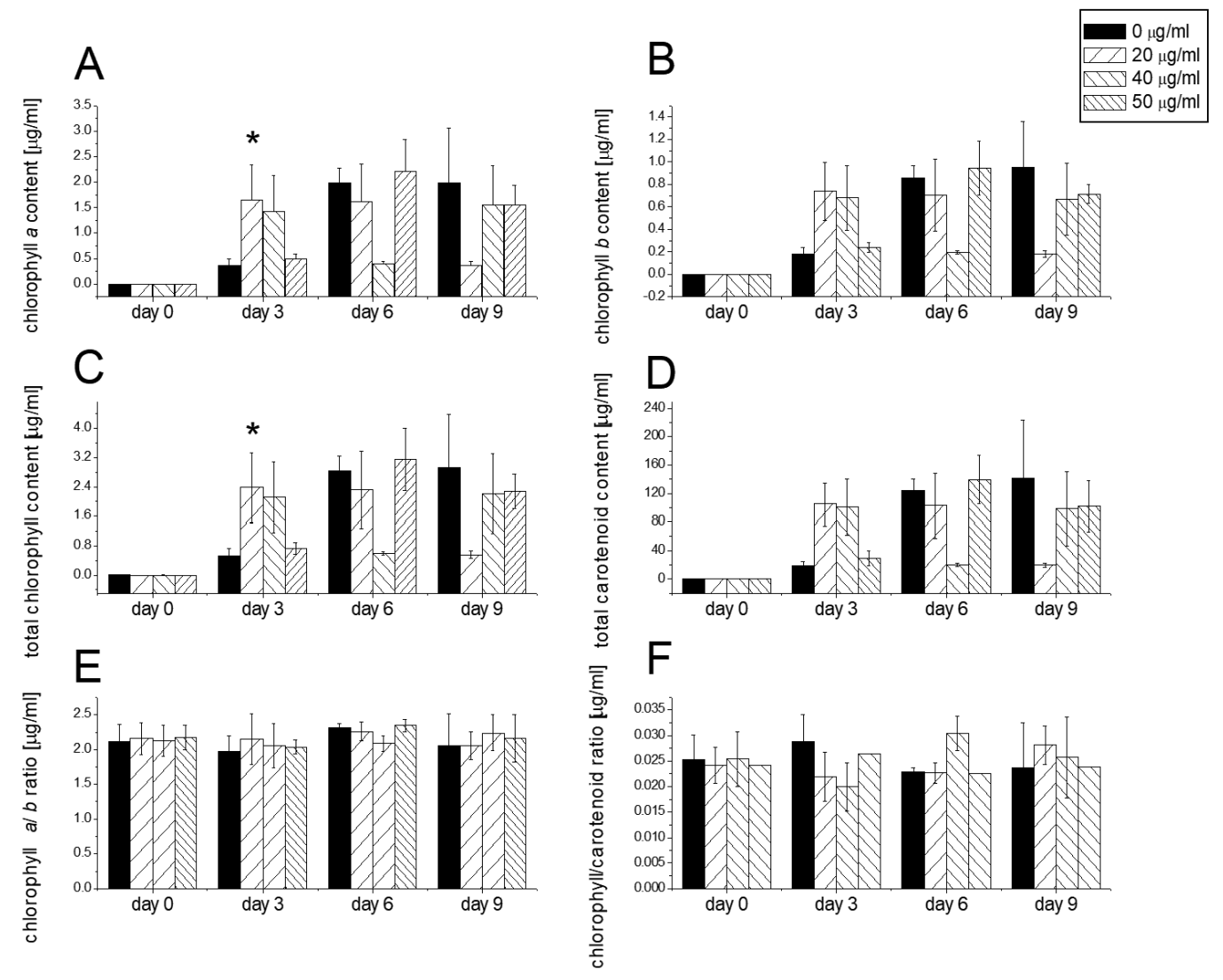

Figure 2. The effect of GF on pigment composition of Chlamydomonas reinhardtii.

Changes in the content of chlorophyll $a(\mathbf{A})$ and $b(\mathbf{B})$, as well as total chlorophyll $(\mathbf{C})$, and total carotenoid (D); (E) the chlorophyll $a / b$ ratio; $(\mathbf{F})$ the chlorophyll to carotenoid ratio. Statistically significant differences $(P<0.05)$ are indicated with *. Error bars - S.D. 

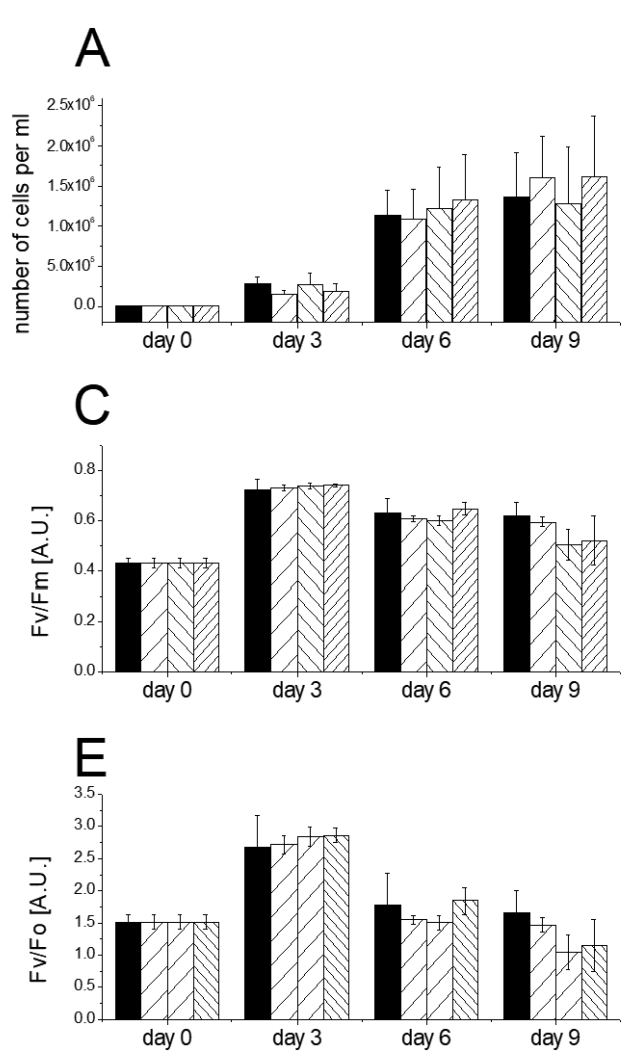
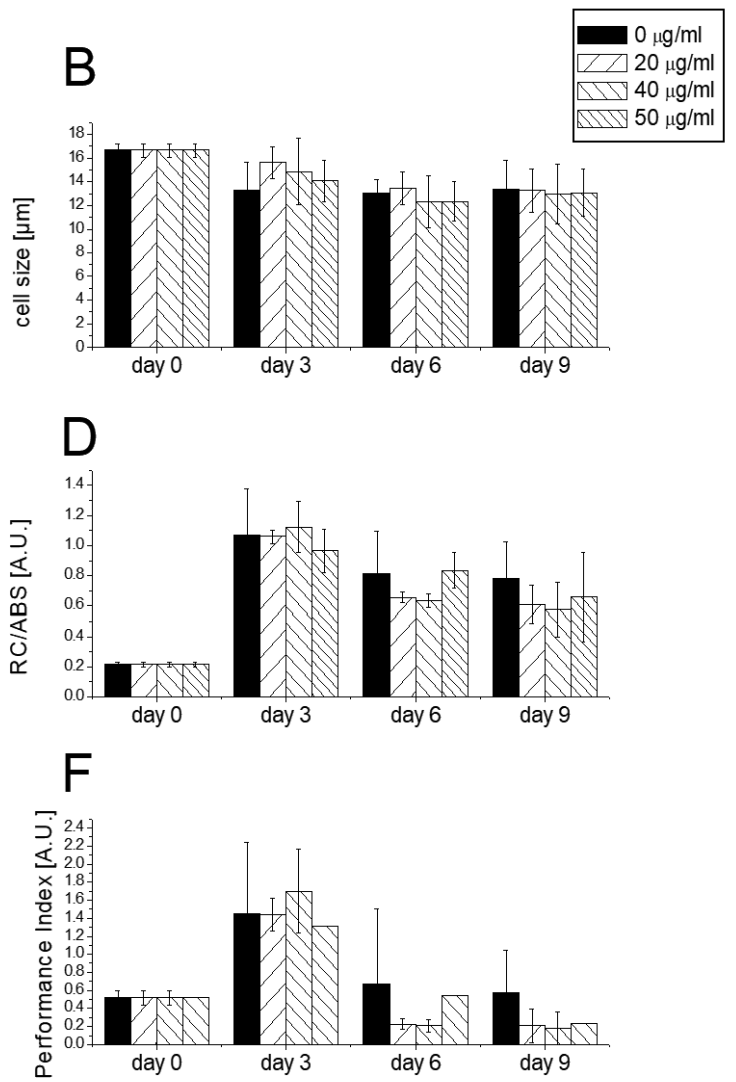

Figure 3. The effect of GF on cell size, number of cells per $\mathrm{ml}$ and selected photosynthetic parameters.

The number of counted cells $(\mathbf{A})$ and cell size $(\mathbf{B})$ measured by a cell counter. The results of fluorimetric measurements of the efficiency of photosystem II - $F_{v} / F_{m}(\mathbf{C})$, the number of chlorophyll molecules per reaction center (D), the efficiency of water-evolving complex (E) and Performance Index (F) indicating overall photosynthesis efficiency. All data were checked for statistically significant differences $(P<0.05)$. Error bars - S.D.

nied by a significant increase of NPQ (Pak et al., 2009; Dongsansuk, 2013), suggesting weaker protection from higher intensities of light. No such change was observed during our experiment. On the contrary, we observed transient stimulation of chlorophyll $a$ accumulation that might be beneficial. No other stimulating effect was observed at the tested concentrations, thus at the current

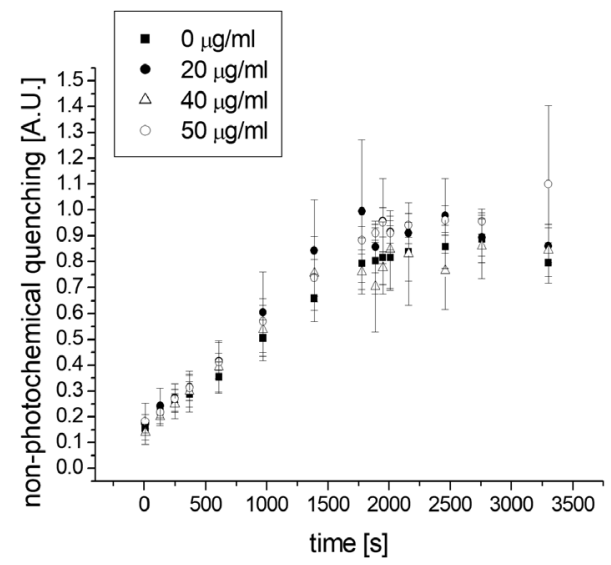

Figure 4. The effect of GF on non-photochemical quenching in C. reinhardtii

The fluorimetric measurements of NPQ in 9-day old cultures of C. reinhardtii. Dark-adapted cultures were irradiated with actinic (saturating photosynthesis) light per $1700 \mathrm{~s}$, then the fluorescence was recorded under pseudo-dark conditions. Statistically significant differences $(P<0.05)$ are indicated with *. Error bars - S.D. stage of research there is no evidence that GF may be considered as a biostimulant of algal growth. However, its low toxicity and little interference with physiology of C. reinhardtii suggest that it can be developed as an excellent delivery system for entrapped ions and growth regulators (as fullerenes may act as cages with time-delayed release of molecules) or as a tool for DNA delivery. Since the GF surface is negatively charged, it may bind cationic molecules. It was shown that such properties may be used for reducing toxicity of heavy metals (Anderson \& Barron, 2005), which may be complexed using hydroxyfullerenes. Furthermore, GF-based technology will be further developed and focused on the role of GF under stress conditions (as surface modified fullerenes enhance particular stress tolerance in plants), lipid accumulation and production of important biomolecules.

\section{Conflicts of interest}

The authors declare that there is no conflict of interest regarding publication of this article.

\section{LITERATURE}

Anderson R, Barron AR (2005) Reaction of hydroxyfullerene with metal salts: a route to remediation and immobilization. $J$ Am Chem Soc 127: 10458-10459. https://doi.org/10.1021/ja051659d

Bedrov D, Smith GD, Davande H, Li L (2008) Passive transport of $\mathrm{C}_{60}$ fullerenes through a lipid membrane: a molecular dynamics simulation study. J Phys Chem B 12: 2078-2084. https://doi. org/10.1021/.jp075149c

Borišev M, Borišev I, Župunski M, Arsenov D, Pajević S, Ćurčić Ž, Vasin J, Djordjevic A (2016) Drought impact is alleviated in sugar 
beets (Beta vulgaris L.) by foliar application of fullerenol nanoparticles. PLoS One 11: e0166248. https://doi.org/10.1371/journal. pone. 0166248

Chen M, Sun Y, Liang J, Zeng G, Li Z, Tang L, Zhu Y, Jiang D, Song B (2019) Understanding the influence of carbon nanomaterials on microbial communities. Environ Int 126: 690-698. https://doi. org/10.1016/j.envint.2019.02.005

Chen M, Zhou S, Zhu Y, Sun Y, Zeng G, Yang C, Xu P, Yan M, Liu Z, Zhang W (2018) Toxicity of carbon nanomaterials to plants, animals and microbes: Recent progress from 2015-present. Chemosphere 206: 255-264. https://doi.org/10.1016/j.chemosphere.2018.05.020.

Chen R, Ratnikova TA, Stone MB, Lin S, Lard M, Huang G, Hudson JS, Ke PC (2010) Differential uptake of carbon nanoparticles by plant and mammalian cells. Small 6: 612-617. https://doi. org/10.1002/smll.200901911

De La Torre-Roche R, Hawthorne J, Deng Y, Xing B, Cai W, Newman LA, Wang C, Ma X, White JC (2012) Fullerene-enhanced accumulation op,p'-DDE in agricultural crop species. Environ Sci Technol 46: 9315-9323. https://doi.org/10.1021/es301982w

Dongsansuk A (2013) The performance of PSII efficiency and growth response to salt stress in three rice varieties differing in salt tolerance. In Molecular Stress Physiology of Plants. Gyana Ranjan Rout Anath Bandhu Das, eds, pp. 87-131 Springer Dordrecht Heidelberg New York London

Foley S, Crowley C, Smaihi M, Bonfils C, Erlanger BF, Seta P, Larroque C (2002) Cellular localization of a water-soluble fullerene derivative, Biochem Biophys Res Commun 294: 116-125. https://doi. org/10.1016/S0006-291X (02)00445-X

Franskevych D, Palyvoda K, Petukhov D, Prylutska S, Grynyuk I, Schuetze C, Drobot L, Matyshevska O, Ritter U (2017) Fullerene C[60]penetration into leukemic cells and its photoinduced cytotoxic effects. Nanoscale Res Lett 12: 40. https://doi.org/10.1186/s11671016-1819-5

Gao J, Wang Y, Folta KM, Krishna V, Bai W, Indeglia P, Georgieva A, Nakamura H, Koopman B, Moudgil B (2011) Polyhydroxy fullerenes (fullerols or fullerenols): beneficial effects on growth and lifespan in diverse biological models. PLoS One 6: e19976. https:// doi.org/10.1371/journal.pone.0019976

Goodarzi S, Da Ros T, Conde J, Sefat F, Mozafari M (2017) Fullerene: biomedical engineers get to revisit an old friend. Materials Today 20 460-480. https://doi.org/10.1016/j.mattod.2017.03.017

Grebowski J, Kazmierska P, Krokosz A (2013) Fullerenols as a new therapeutic approach in nanomedicine. Biomed Res Int 2013: 751913. https://doi.org/10.1155/2013/751913

Hollander M, Wolfe DA (1973) Nonparametric Statistical Methods. New York: John Wiley \& Sons. pp. 115-120.

Huang YY, Sharma SK, Yin R, Agrawal T, Chiang LY, Hamblin MR (2014) Functionalized fullerenes in photodynamic therapy. J Biomed Nanotechnol 10: 1918-1936. https://doi.org/10.1166/jbn.2014.1963

Husen A, Siddiqi KS (2014) Carbon d fullerene nanomaterials in plant system. J Nanobiotechnology 12: 16. https://doi.org/10.1186/14773155-12-16

Hussein MM, Mehanna H, Zaki SN, Nagwan FAH (2014) Influences of salt stress and foliar fertilizers on growth, chlorophyll and carotenoids of jojoba plants. Middle East J Agric Res 3: 221-226.

Injac R, Prijatelj M, Strukelj B (2013) Fullerenol nanoparticles: toxicity and antioxidant activity. Methods Mol Biol 1028: 75-100. https://doi. org/10.1007/978-1-62703-475-3_5

Kalaji HM, Schansker G, Ladle RJ, Goltsev V, Bosa K, Allakhverdiev SI, Brestic M, Bussotti F, Calatayud, Dabrowski P, Elsheery NI, Ferroni L, Guidi L, Hogewoning SW, Jajoo A, Misra AN, Nebauer SG, Pancaldi S, Penella C, Poli D, Pollastrini M, RomanowskaDuda ZB, Rutkowska B, Serôdio J, Suresh K, Szulc W, Tambussi E, Yanniccari M, Zivcak M (2014) Frequently asked questions about in vivo chlorophyll fluorescence: practical issues. Photosynth Res Nov 122: 121-158. https://doi.org/10.1007/s11120-014-0024-6

Kole C, Kole P, Randunu KM, Choudhary P, Podila R, Ke PC, Rao AM, Marcus RK (2013) Nanobiotechnology can boost crop production and quality: first evidence from increased plant biomass, fruit yield and phytomedicine content in bitter melon (Momordica charantia). BMC Biotechnol 13: 37. https://doi.org/10.1186/1472-6750rantia).

Landa P, Vankova R, Andrlova J, Hodek J, Marsik P, Storchova H, White JC, Vanek T (2012) Nanoparticle-specific changes in Arabidopsis thaliana gene expression after exposure to $\mathrm{ZnO}, \mathrm{TiO}_{2}$, and fullerene soot. I Hazard Mater 241-242: 55-62. https://doi. org/10.1016/j.jhazmat.2012.08.059

Lapin NA, Krzykawska-Serda M, Dilliard S, Mackeyev Y, Serda M, Wilson LJ, Curley SA, Corr SJ (2017) The effects of non-invasive radiofrequency electric field hyperthermia on biotransport and biodistribution of fluorescent [60] fullerene derivative in a murine orthotopic model of breast adenocarcinoma. J Controlled Release 260: 92-99. https://doi.org/10.1016/j.jconrel.2017.05.022.

Lichtenthaler HK (1987) Chlorophylls and carotenoids: pigments of photosynthetic membranes. Methods Enaymol 148: 350-382
Lin S, Reppert J, Hu Q, Hudson JS, Reid ML, Ratnikova TA, Rao AM, Luo H, Ke PC (2009) Uptake, translocation, and transmission of carbon nanomaterials in rice plants. Small 5: 1128-1132. https:// doi.org/10.1002/smll.200801556

Liu Q, Chen B, Wang Q, Shi X, Xiao Z, Lin J, Fang X (2009) Carbon nanotubes as molecular transporters for walled plant cells. Nano Lett 9: 1007-1010. https://doi.org/10.1021/nl803083u

Liu Q, Zhao Y, Wan Y, Zheng J, Zhang X, Wang C, Fang X, Lin J (2010) Study of the inhibitory effect of water-soluble fullerenes on plant growth at the cellular level. ACS Nano 4: 5743-5748. https:// doi.org/10.1021/nn101430g

Lucafo M, Gerdol M, Pallavicini A, Pacor S, Zorzet S, Da Ros T, Prato M, Sava G (2013) Profiling the molecular mechanism of fullerene cytotoxicity on tumor cells by RNA-seq. Toxicology 314: 183-192. https://doi.org/10.1016/j.tox.2013.10.001

Ma H, Liang XJ (2010) Fullerenes as unique nanopharmaceuticals for disease treatment. Sci China Chem 53: 2233-2240. https://doi. org $/ 10.1007 /$ s11426-010-4118-5

Maeda-Mamiya R, Noiri E, Isobe H, Nakanishi W, Okamoto K, Doi $\mathrm{K}$, Sugaya T, Izumi T, Homma T, Nakamura E (2010) In vivo gene delivery by cationic tetraamino fullerene. Proc Natl Acad Sci USA 107: 5339-5344. https://doi.org/10.1073/pnas.0909223107.

Maxwell K, Johnson GN (2000) Chlorophyll fluorescence - a practical guide. J Exp Bot 51: 659-668. https://doi.org/10.1093/jexbot/51.345.659

Misra AN, Misra M, Singh R (2012) Chlorophyll fluorescence in plant biology. In Biophysics, Misra AN ed, pp 171-192. Rijeka, Croatia: InTech. 10.5772/1877

Pak VA, Nabipour M, Meskarbashee M (2009) Effect of salt stress on chlorophyll content, fluorescence, $\mathrm{Na}^{+}$and $\mathrm{K}^{+}$ions content in rape plants (Brassica napus L.). Asian J Agric Res3: 28-37. https://doi. org/10.3923/ajar.2009.28.37

Prasad MN, Drej K, Skawińska A, Strzałka K (1998) Toxicity of cadmium and copper inChlamydomonasreinhardtii wild-type (WT 2137) and cell wall deficient mutant strain (CW 15). Bull Environ Contam Toxicol 60: 306-11

Prylutska SV, Grynyuk II (2008) Anti-oxidant properties of $\mathrm{C}_{60}$ fullerenes in vitro. Fuller Nanotub Carbon Nanostruct 16: 698-705. https://doi.org/10.1080/15363830802317148

Prylutska SV, Skivka LM (2015) Complex of $\mathrm{C}_{60}$ fullerene with doxorubicin as a promising agent in antitumor therapy. Nanosc Res Lett 10: 499. https://doi.org/10.1186/s11671-015-1206-7

R Core Team (2019). R: A language and environment for statistical computing. R Foundation for Statistical Computing, Vienna, Austria. URL https://www.R-project.org/

Qiao R, Roberts AP, Mount AS, Klaine SJ, Ke PC (2007) Translocation of $\mathrm{C}_{60}$ and its derivatives across a lipid bilayer. Nano Lett 7: 614-619. https://doi.org/10.1021/nl062515f

Rasala BA, Mayfield SP (2015) Photosynthetic biomanufacturing in green algae; production of recombinant proteins for industrial, nutritional, and medical uses. Photosynth Res 123: 227-239. https://doi. org/10.1007/s11120-014-9994-7

Rico CM, Majumdar S, Duarte-Gardea M, Peralta-Videa JR, GardeaTorresdey J (2011) Interaction of nanoparticles with edible plants and their possible implications in the food chain. I Agric Food Chem 59: 3485-3498. https://doi.org/10.1021/jf104517j

Rizvi SAA, Saleh AM (2017) Applications of nanoparticle systems in drug delivery technology. Saudi Pharm J 26: 64-70. https://doi. org/10.1016/j.jsps.2017.10.012

Roy P, Bag S, Chakraborty D, Dasgupta S (2018) Exploring the inhibitory and antioxidant effects of fullerene and fullerenol on ribonuclease A. ACS Omega 3: 12270-12283. https://doi.org/10.1021/ acsomega.8b01584

Sachkova AS, Kovel ES, Churilov GN, Guseynov OA, Bondar AA, Dubinina IA, Kudryasheva NS (2017) On mechanism of antioxidant effect of fullerenols. BB Reports 9: 1-8. https://doi.org/10.1016/j. bbrep.2016.10.011

Sager R, Granick S (1953) Nutritional studies with Chlamydomonas reinbardi. Ann New York Acad Sci 56: 831-838

Sairam RK, Tyagi A (2004) Physiological and molecular biology of salinity stress tolerance in plants. Curr Sci 86: 407-420. https://doi. org/10.1007/1-4020-4225-6

Sayes CM, Fortner JD, Guo W, Lyon D, Boyd AM, Ausman KD, Tao YJ, Sitharaman B, Wilson LJ, Hughes JB, West JL, Colvin WL (2004) the differential cytotoxicity of water-soluble fullerenes. Nano Letters 4: 1881-1887. https://doi.org/10.1021/n10489586

Scoma A Faraloni C, Giannelli L (2015) Advances in the biotechnology of hydrogen production with the microalga Chlamydomonas reinbardtii. Crit Rev Biotechnol 35: 485-496. https://doi.org/10.3109/073 88551.2014.900734

Scranton MA, Ostrand JT, Fields FJ, Mayfield SP (2015) Chlamydomonas as a model for biofuels and bio-products production. Plant J 82: 523-531. https://doi.org/10.1111/tpj. 12780

Serda M, Nalepa P, Musioł R (2018b) Diglicinederivative of [60]fullerene and the methods of synthesis thereof. Polish Patent Application, P. 428469 . 
Serda M, Ware MJ, Newton JM, Sachdeva S, Krzykawska-Serda M, Nguyen L, Law J, Anderson AO, Curley SA, Wilson LJ, Corr SJ (2018a) Nanomedicine (Lond) 13: 2981-2993

Sharma SK, Chiang LY, Hamblin MR (2011) Photodynamic therapy with fullerenes in vivo: reality or a dream? Nanomedicine 6: 1813-1825. https://doi.org/10.2217/nnm.11.144.

Siegel S, Castellan J (1988) Non parametric statistics for the behavioural sciences, pp 213-221. MacGraw Hill Int., New York

Tyurin DP, Kolmogorov FS, Cherepkova IA, CharykovN, Semenov K, KeskinovV, Safyannikov NA, PukharenkoYuV, Letenko DG, Segeda TA, Shaimardanov Z (2018) Antioxidant properties of fullerenol-d. Nanosystems: Physics, Chemistry, Mathematics 9: 798-810. https:// doi.org/10.17586/2220-8054-2018-9-6-798-810

Wang C, Chang XL, Shi Q, Zhang X (2018) Uptake and transfer of (13)C-fullerenols from Scenedesmus obliquus to Daphnia magna in an aquatic environment. Environ Sci Technol 29: (Epub ahead print) https://doi.org/10.1021/acs. est. 8b03121.
Wang Y, Westerhoff P, Hristovski KD (2011) Fate and biological effects of silver, titanium dioxide, and $\mathrm{C}_{60}$ (fullerene) nanomaterials during simulated wastewater treatment processes. I Hazard Mater 201-202: 16-22. https://doi.org/10.1016/j.jhazmat.2011.10.086

Yin R, Wang M, Huang YY, Landi G, Vecchio D, Chiang LY, Hamblin MR (2015) Antimicrobial photodynamic inactivation with decacationic functionalized fullerenes: oxygen-independent photokilling in presence of azide and new mechanistic insights. Free Radic Biol Med 79: 14-27. https://doi.org/10.1016/j.freeradbiomed.2014.10.514

Zhang LW, Yang J, Barron AR, Monteiro-Riviere NA (2009) Endocytic mechanisms and toxicity of a functionalized fullerene in human cells. Toxicol Lett 191: 149-157. https://doi.org/10.1016/j. toxlet.2009.08.017.

Zhao L, Ji Y, Sun P, Li R, Xiang F, Wang H, Ruiz-Martinez J, Yang $\mathrm{Y}$ (2018) Effects of individual and complex ciprofloxacin, fullerene $\mathrm{C}[60]$, and $\mathrm{ZnO}$ nanoparticles on sludge digestion: Methane production, metabolism, and microbial community. Bioresour Technol 267: 46-53. https://doi.org/10.1016/j.biortech.2018.07.024 